\title{
Failure of Alglucerase Infused into Gaucher Disease Patients to Localize in Marrow Macrophages
}

\author{
Ernest Beutler, Wanda Kuhl, and Luke M. Vaughan \\ Department of Molecular and Experimental Medicine, \\ The Scripps Research Institute, La Jolla, California, U.S.A.
}

\begin{abstract}
Background: Gaucher disease is a common glycolipid storage disease, caused by a deficiency of lysosomal $\beta$-glucosidase (glucocerebrosidase). Alglucerase is a form of glucocerebrosidase enriched with terminal mannose moieties, so as to "target" the preparation to the highaffinilty macrophage receptor in patients with Gaucher disease. Our earlier in vitro studies indicated that alglucerase was bound by cells other than macrophages by a widely distributed, low-affinity mannose receptor.

Materials and Methods: Bone was removed at surgery from six patients with Gaucher disease; in three cases, bone was obtainable both when the patient was untreated and after receiving an infusion of alglucerase. Four samples of bone were obtained from patients without Gaucher disease and served as controls. A bone marrow aspirate was obtained from another patient with
\end{abstract}

Gaucher disease immediately after enzyme infusion. Marrow $\beta$-glucosidase activity and chitotriosidase (a macrophage marker) was determined on all samples.

Results: Even with the large bolus doses used for the treatment of Gaucher disease by some, scarcely any $\beta$-glucosidase activity was found in marrow samples; the amount of the enzyme was much less than would have been anticipated had the enzyme been evenly distributed to all body cells.

Conclusions: Alglucerase is not targeted to marrow macrophages. Its unquestioned therapeutic effectiveness must be due either to its activity at some site other than marrow macrophages or to the fact that the doses administered are so enormous that even a small fraction is sufficient to achieve a therapeutic effect.

\section{INTRODUCTION}

Gaucher disease is the most common glycolipid storage disorder, with an estimated incidence of approximately 1:800 in the Ashkenazi Jewish population. The disease phenotype is manifested in macrophages, which become engorged with glucocerebroside as a result of the glucocerebrosidase deficiency that causes this disease.

Aside from allogeneic marrow transplantation, the only treatment effective in reversing glycolipid storage in Gaucher disease is the infusion of glucocerebrosidase that has been modified by removing outer sugars to expose inner mannose moieties. Such enzyme (alglucerase; Ceredase) has been designated as "macrophage targeted", because of the belief that it is specifi-

Address correspondence and reprint requests to: Ernest Beutler, Department of Molecular and Experimental Medicine, The Scripps Research Institute, 10666 North Torrey Pines Road, La Jolla, CA 92037, U.S.A. cally bound by the mannose receptor of macrophages.

However, in studies in vitro we found that alglucerase was bound by receptors found on all cell types tested, and that the specific mannose receptor accounted only for a minute amount of the binding observed (1). We now present in vivo data, obtained from six Gaucher disease patients undergoing joint replacement and one patient whose marrow was obtained by aspiration, that show that far from being macrophage targeted, very little of the infused enzyme reaches the marrow.

\section{MATERIALS AND METHODS}

\section{Sources of Marrow Samples}

Bone specimens were obtained from six patients with type I Gaucher disease. Each was undergo- 
ing either surgical joint replacement or a revision of a joint replacement. In the case of Patients 1 , 4 , and 6, the bone came from the femur. The sample from Patient 2 was from the knee, and the first (pretreatment) sample from Patient 3 from the shoulder and the second, (post-treatment) sample from the acetabulum (assay on the femoral head gave similar results). In three instances, we were fortunate enough to be able to obtain bone from the same patient on two occasions, one while receiving alglucerase therapy and one when not being treated with alglucerase. An iliac crest marrow needle aspirate was obtained from a seventh patient with Gaucher disease and from two normal volunteers. Three control surgical bone specimens were obtained from the hip and one from the lumbar spine from four patients without Gaucher disease undergoing joint replacement surgery.

\section{Sample Preparation and Assay Procedures}

Surgical bone samples (Table 1) were packed in dry ice and transported to our laboratory, where they were stored in a $-70^{\circ} \mathrm{C}$ freezer until assay. Each sample was homogenized in a Orthoblend Bone Mill (distributed by Zimmer, Warsaw, Indiana), the bone chips were removed by centrifugation, and enzyme activity was determined by the method of Raghaven et al. (2). The cells from marrow aspirate (Table 2) were fractionated with Ficoll-Hypaque, and the adherent cells from the interface fraction (3) were assayed for $\beta$-glucosidase activity using the method of Raghaven et al. (2). DNA levels were determined by the method of Labarca and Paigen (4), and $\beta$-glucosidase activity was expressed as U/g DNA. Chitotriosidase activity was measured by a minor modification of the method of Hollak et al. (5).

\footnotetext{
Alglucerase Infusions

Commercially available alglucerase (Ceredase; Genzyme Corp., Boston, MA, U.S.A.) was diluted in physiological saline solution and infused intravenously over a period of $2 \mathrm{hr}$ into each of five patients. In the case of three of the patients (Patients 4, 5, and 7), the enzyme infusion was concluded immediately before entering the operating room or performing the marrow aspiration; in the case of Patient 3, it was given $8 \mathrm{hr}$ before surgery; and in the case of Patient 6 , it was given $48 \mathrm{hr}$ before surgery.
}

\section{RESULTS}

The results of the $\beta$-glucosidase activity measurements are summarized in Tables 1 and 2. As expected, the activity in bone from Gaucher disease patients ranged from one fifth to one tenth of that from normal subjects. After infusion of alglucerase, only a very small increase in enzyme activity was found in each of the three patients, much less than calculated even if the distribution of the enzyme had been uniform to all body cells (see below).

The chitotriosidase activity of normal marrow exceeded that of peripheral blood lymphocytes (N.V. = $1.1 \mathrm{U} / \mathrm{g}$ DNA) (unpublished), a finding consistent with that expected from a macrophage-rich tissue. The activity of the enzyme was greatly increased in most of the marrow samples from patients with Gaucher disease, indicating that Gaucher cells were probably present in the samples, since these cells are known to be very rich in chitotriosidase.

\section{DISCUSSION}

Enzyme replacement therapy for glycolipid storage diseases was first proposed by De Duve (6) and has seemed a particularly promising therapeutic approach to the treatment of Gaucher disease because macrophages function to remove material from the circulating blood and, if glucocerebrosidase were introduced into the circulation, macrophage uptake might result in enzymatic removal of the storage lipid. Enzyme therapy was first attempted by Brady et al., who infused unmodified enzyme into the circulation in 1974 (7). Although it was claimed that there was a significant decrease in the amount of glucocerebroside in the liver and in erythrocytes, no therapeutic effect was achieved. We targeted the enzyme to macrophages by incorporating it into erythrocyte ghosts (8), as had first been proposed by Ihler et al. (9), and by coating the cells with immunoglobulin to enhance uptake by macrophages. This approach, used in seven patients, proved very effective in targeting the enzyme to macrophages in vitro (10) and in vivo (11). In one patient, a decrease in liver size was observed. However, because the amount of enzyme we were able to purify in a research laboratory was very small and the efficiency of entrapment was not very high, this approach seemed impractical and was abandoned.

Achord and Sly (12) suggested that the man- 
TABLE 1. The $\beta$-glucosidase activity of bone removed from patients with and without Gaucher disease (GD) before and after infusion with alglucerase

\begin{tabular}{|c|c|c|c|c|}
\hline & \multicolumn{3}{|c|}{ B-Glucosidase Activity (U/g DNA) } & \multirow{2}{*}{$\begin{array}{c}\text { Chitotriosidase } \\
\text { (U/g DNA) }\end{array}$} \\
\hline & Untreated & Treated & Expected $^{a}$ & \\
\hline Normal Controls (4) & $9.3 \pm 5.3$ & - & - & $10.0 \pm 7.00$ \\
\hline GD Patient 1 & 0.8 & - & - & 16 \\
\hline GD Patient 2 & 1.5 & - & - & 64 \\
\hline GD Patient 3 & 0.8 & $7.7^{b}$ & $>300$ & $(48,76)^{c}$ \\
\hline GD Patient 4 & 0.7 & $3.2^{d}$ & $>11.5$ & $(110,129)$ \\
\hline GD Patient 5 & 1.5 & $2.6^{e}$ & $>600$ & $(215, \mathrm{~N} / \mathrm{A})$ \\
\hline GD Patient 6 & - & $2.0^{f}$ & $>4.7$ & $(\mathrm{~N} / \mathrm{A}, 70)$ \\
\hline
\end{tabular}

Normal values are mean \pm 1 standard deviation. N/A, not available.

${ }^{a}$ Expected values are those that would be achieved if the infused enzyme were uniformly distributed to all body cells and remained with a $t_{1 / 2}$ of $8 \mathrm{hr}$.

${ }^{b}$ Bone taken $8 \mathrm{hr}$ after infusion of $60 \mathrm{U}$ alglucerase $/ \mathrm{kg}$ body wt.

'Values in parentheses are pre- and postinfusion values, respectively.

${ }^{d}$ Bone taken at end of 2 -hr infusion of $1.15 \mathrm{U}$ alglucerase $/ \mathrm{kg}$ body wt.

${ }^{e}$ Bone taken at end of 2 -hr infusion of $60 \mathrm{U}$ alglucerase $/ \mathrm{kg}$ body wt.

${ }^{f_{B}}$ Bone taken $48 \mathrm{hr}$ after infusion of $60 \mathrm{U}$ alglucerase/kg body wt.

nose receptor of macrophages might provide a route for efficient delivery of enzyme in Gaucher disease. Enhanced uptake of glucocerebrosidase by murine liver was demonstrated to occur when enzyme with increased exposed mannose content was infused $(13,15)$. Enzyme modified in this way was produced commercially as alglucerase (Ceredase), and has been designated "macrophage targeted".

We obtained bone removed during joint replacement therapy from six patients with Gaucher disease and from a seventh patient on whom marrow aspiration was performed imme-

TABLE 2. The $\beta$-glucosidase activity of adherent cells from bone marrow aspirates removed from two normal volunteers and from a patient with Gaucher disease immediately after infusion of $60 \mathrm{U}$ alglucerase per kg body wt

及-Glucosidase Activity (U/g DNA)

$\begin{array}{lc}\text { Normal Controls } & 4.3,6.2 \\ \text { GD Patient } 7 & 0.9\end{array}$

diately after enzyme infusion. The extracts were rich in chitotriosidase activity, indicating that they were rich in macrophages. After infusion of alglucerase into five patients, three of whom had assays performed when not receiving alglucerase therapy, an increase of $\beta$-glucosidase activity of 1.7- to 9.6-fold were documented. This range agrees with a single observation reported by Barton et al (16) of an 8 -fold increase in $\beta$-glucosidase activity, but not with the report by Fallet et al (17) that there was an increase to approximately 12 -fold of normal $19 \mathrm{hr}$ after a dose of 30 $\mathrm{U}$ alglucerase $/ \mathrm{kg}$ and of 8 -fold of normal 10 days after infusion of $60 \mathrm{U} / \mathrm{Kg}$ of alglucerase into Gaucher disease patients. Indeed, even if the enzyme level were markedly increased after infusion of enzyme, with an apparent intracellular half-life for exogenously introduced enzyme of about 8 hr $(1,18,19)$, it is difficult to understand how an elevation could persist through 30 half-lives.

Since the average DNA content of human tissues is $100 \mathrm{mg} \mathrm{DNA} / \mathrm{Kg}$ body weight, uniform distribution of $60 \mathrm{U} / \mathrm{Kg}$ of infused enzyme should have immediately increased the enzyme activity of the bone by 60 units of enzyme per $100 \mathrm{mg}$ of DNA, or 600 units of enzyme per gram of DNA. The infusion of $1.15 \mathrm{U} / \mathrm{kg}$ body $\mathrm{wt}$ would have increased the enzyme activity by 
$11.5 \mathrm{U} / \mathrm{g}$ of DNA. Yet, the actual increase, even in the patients receiving the largest dosage, was less than $7 \mathrm{U} / \mathrm{g}$ DNA in each of the four patients. Thus, as shown in the table, the amount of enzyme actually found in all of the treated patients was much less than would have been expected if the enzyme had been equally distributed to all body cells. In the case of Patient 4 , who received $60 \mathrm{U} / \mathrm{kg}$, the amount actually found was only $0.2 \%$ of what might have been expected with uniform distribution of enzyme to all body cells. In the case of Patient 6, bone sampling was carried out $48 \mathrm{hr}$ after enzyme infusion. Intracellular enzyme half-life has been estimated to be approximately $8 \mathrm{hr}$. This would lead to an estimated increment of $4.7 \mathrm{U} / \mathrm{g}$ DNA had the enzyme been equally distributed to all body cells and disappeared with a $t_{1 / 2}$ of $8 \mathrm{hr}$. A total of only $2 \mathrm{U} / \mathrm{g}$ very close to normal baseline was found.

Marrow from bones surrounding the proximal joints is rich in macrophages, as documented here by the measurement of chitotriosidase activity, an enzyme that appears only as monocytes mature into macrophages. The lack of $\beta$-glucosidase activity in this marrow after alglucerase infusion indicates that this preparation is not only not targeted to marrow macrophages as hoped, but it is preferentially removed from the circulation at other sites, very likely the vascular endothelium or endothelium of the liver. It is conceivable that marrow macrophages are, in some respect, unique and that preferential uptake occurs in other organs, such as liver and spleen. However, it is notable that the response to alglucerase of marrow function is readily demonstrated, and yet, very little of the infused enzyme can be found there. Measurements in other organs such as liver and spleen are not ethically feasible. The mechanism by which alglucerase is therapeutically effective is unclear. It is not macrophage targeted.

\section{ACKNOWLEDGMENTS}

We appreciate the cooperation of our patients in making samples available to us and to Harlan C. Amstutz, MD, C. A. Chalian, MD, and John P. Heiner, MD, for collecting and shipping bone samples to us. This is Manuscript 8967-MEM from The Scripps Research Institute. This work was supported by National Institutes of Health Grants DK36639 and RR00833 and the Stein Endowment Fund.

\section{REFERENCES}

1. Sato Y, Beutler E. (1993) Binding, internalization, and degradation of mannose-terminated glucocerebrosidase by macrophages. $J$. Clin. Invest. 91: 1909-1917.

2. Raghavan SS, Topol J, Kolodny EH. (1980) Leukocyte beta-glucosidase in homozygotes and heterozygotes for Gaucher disease. Am. J. Hum. Genet. 32: 158-173.

3. Beutler E, Kuhl W, Matsumoto F, Pangalis G. (1976) Acid hydrolases in leukocytes and platelets of normal subjects and in patients with Gaucher's and Fabry's disease. J. Exp. Med. 143: 975-980.

4. Labarca C, Paigen K. (1980) A simple, rapid, and sensitive DNA assay procedure. Anal. Biochem. 2: 344-352.

5. Hollak CEM, van Weely S, van Oers MHJ, Aerts JMFG. (1994) Marked elevation of plasma chitotriosidase activity. A novel hallmark of Gaucher disease. J. Clin. Invest. 93: 1288-1292.

6. De Duve C. (1964) From cytases to lysosomes. Fed. Proc. 23: 1045-1049.

7. Brady RO, Pentchev PG, Gal AE, Hibbert SR, Dekaban AS. (1974) Replacement therapy for inherited enzyme deficiency. Use of purified glucocerebrosidase in Gaucher's disease. N. Engl. J. Med. 291: 989-993.

8. Dale GL, Beutler E. (1976) Enzyme replacement therapy in Gaucher's disease: A rapid high-yield method for purification of glucocerebrosidase. Proc. Natl. Acad. Sci. U.S.A. 73: 4672-4674.

9. Ihler GM, Glew RH, Schnure FW. (1973) Enzyme loading of erythrocytes. Proc. Natl. Acad. Sci. U.S.A. 70: 2663-2666.

10. Dale GL, Kuhl W, Beutler E. (1979) Incorporation of glucocerebrosidase into Gaucher's disease monocytes in vitro. Proc. Natl. Acad. Sci. U.S.A 76: 473-475.

11. Beutler E, Dale GL, Kuhl W. (1977) Enzyme replacement with red cells. N. Engl. J. Med. 296: 942-943.

12. Achord DT, Brot FE, Bell CE, Sly WS. (1978) Human beta-glucuronidase: In vivo clearance and in vitro uptake by a glycoprotein recognition system on reticuloendothelial cells. Cell 15: 269-278.

13. Furbish FS, Oliver KL, Zirzow GC, Brady RO, Barranger JA. (1984) Interaction of human placental glucocerebrosidase with hepatic lectins. In: Barranger JA, Brady RO (eds). 
Molecular Basis of Lysosomal Storage Disorders. Academic Press, New York, pp. 219-232.

14. Doebber TW, Wu MS, Bugianesi RL, et al. (1982) Enhanced macrophage uptake of synthetically glycosylated human placental beta-glucocerebrosidase. J. Biol. Chem. 257: 2193-2199.

15. Murray GJ, Doebber TW, Shen TY, et al. (1985) Targeting of synthetically glycosylated human placental glucocerebrosidase. Biochem. Med. 34: 241-246.

16. Barton NW, Brady RO. (1994) Gaucher disease: Skeletal responses to enzyme replacement therapy. Gaucher Clin. Perspect. 2: 8-1 1.

Contributed by E. Beutler on December 28, 1994.
17. Fallet S, Sibille A, Mendelson R, Shapiro D, Hermann G, Grabowski GA. (1992) Enzyme augmentation in moderate to life-threatening Gaucher disease. Pediatr. Res. 31: 496502.

18. Pentchev PG, Kusiak JW, Barranger JA, et al. (1978) Factors that influence the uptake and turnover of glucocerebrosidase and alpha-galactosidase in mammalian liver. $A d v$. Exp. Med. Biol. 101: 745-752.

19. Beutler E. (1993) Gaucher disease as a paradigm of current issues regarding single gene mutations of humans. Proc. Natl. Acad. Sci. U.S.A. 90: 5384-5390. 